\title{
PENGADILAN HIBRIDA (HYBRID COURT) SEBAGAI ALTERNATIF PENANGANAN KEJAHATAN INTERNASIONAL
}

\author{
Arie Siswanto \\ Staf Pengajar Fakultas Hukum Universitas Kristen Satya Wacana \\ Korespondensi: ariesiswanto@yahoo.com
}

\begin{abstract}
Abstrak
Sejak akhir Perang Dunia II, masyarakat internasional menyaksikan meningkatnya upaya serius untuk menanggulangi kejahatan internasional. Selain pengadilan pidana nasional dan mahkamah internasional murni, forum yang baru-baru ini digunakan untuk menangani kejahatan internasional adalah pengadilan hibrida yang telah dibentuk di beberapa negara seperti Kamboja, Sierra Leone dan Timor-Leste. Pengadilan hibrida tersebut dibentuk dengan latar belakang politik berbeda-beda, tetapi sebagai institusi yuridis, pembentukannya seyogianya didasarkan pada instrumen yuridis. Artikel ini mengidentifikasi ada tiga pola dalam pembentukan pengadilan hibrida, yaitu: pembentukan pengadilan hibrida atas dasar perjanjian antara PBB dan negara terkait, pembentukan pengadilan hibrida oleh PBB atau pemerintahan internasional dan pembentukan pengadilan hibrida oleh suatu negara yang kemudian memperoleh dukungan masyarakat internasional.
\end{abstract}

\section{Kata-kata Kunci: Pengadilan Hibrida; Kejahatan Internasional}

\begin{abstract}
Since the end of World War II, the international community witnessed the increasingly serious efforts to deal with the international crimes. Besides the domestic criminal courts and purely international tribunals, the forum that is also recently used to handle international crimes is the hybrid courts that have been established in several places such as in Cambodia, Sierra Leone and Timor-Leste. Hybrid courts are established from different political backgrounds, but as a legal institution, its establishment was necessarily based on legal instruments. This paper identifies that there are three patterns in the formation of hybrid court, which are: the establishment of a hybrid court based on an agreement between the UN and the relevant state, the establishment of a hybrid court by the UN or international administration and the establishment of a hybrid court by a country which later gains greater international support.
\end{abstract}

Keywords: Hybrid Courts; International Crimes 


\section{PENDAHULUAN}

Sejak berakhirnya Perang Dunia II, masyarakat internasional menyaksikan upaya-upaya yang semakin serius untuk menangani kejahatan internasional. Bermula dari Mahkamah Militer Internasional Nurnberg dan Tokyo, gagasan untuk menghapuskan impunitas bagi pelaku kejahatankejahatan internasional semakin menemukan bentuknya.

Secara tradisional, ada dua forum pengadilan yang bisa diharapkan untuk menangani peristiwa kejahatan internasional, yaitu forum pengadilan pidana nasional dan forum pengadilan/ mahkamah pidana yang bersifat internasional seperti Mahkamah Militer Internasional Nurnberg dan Tokyo, International Criminal Tribunal for the Former Yugoslavia (ICTY), International Criminal Tribunal for Rwanda (ICTR) dan International Criminal Court (ICC). Namun, sejak era tahun 1990-an, dunia juga menyaksikan munculnya sebuah genre baru pengadilan yang berada dalam ruang peralihan di antara pengadilan pidana domestik dengan pengadilan/mahkamah pidana yang murni bersifat internasional.

Saat ini ada beberapa pengadilan hibrida seperti itu, antara lain di Sierra Leone, Kamboja, Timor Leste dan yang terakhir, di Lebanon. Pembentukan pengadilan-pengadilan hibrida tersebut tentu saja tidak lepas dari latar belakang dinamika politik. Namun, sebagai sebuah institusi hukum, pengadilanpengadilan hibrida itu juga harus dibentuk berdasarkan dasar-dasar hukum yang pasti. Dalam konteks itulah tulisan ini dimaksudkan untuk mengkaji tentang bagaimana pola pembentukan pengadilan-pengadilan hibrida, dilihat dari dasar hukum pembentukannya.

Bagian awal dari tulisan ini mengemukakan tentang konsep kejahatan internasional yang masuk dalam kategori kewenangan pengadilanpengadilan hibrida. Selanjutnya, akan dikemukakan pula tentang kesulitankesulitan penanganan kejahatan internasional melalui mekanisme tradisional (pengadilan pidana nasional dan pengadilan/mahkamah yang bersifat internasional), yang berujung pada relevansi pengadilan hibrida. bagian akhir dari tulisan ini mengungkapkan hasil kajian terhadap dokumen-dokumen hukum terkait dengan pembentukan pengadilanpengadilan hibrida, yang dimaksudkan untuk memetakan pola-pola pembentukan pengadilan hibrida.

\section{PEMBAHASAN}

\section{Pengertian dan Latar Belakang Pembentukan "Pengadilan Hibrida"}

Sebelum membahas lebih lanjut tentang pengadilan hibrida, perlu dikemukakan terlebih dahulu uraian tentang kejahatan internasional. Uraian ini penting mengingat bahwa pengadilan-pengadilan hibrida sejauh ini hanya dibentuk untuk menangani perbuatan-perbuatan yang dikategorikan sebagai kejahatan internasional (international crimes). 
Pengertian "kejahatan internasional"

Salah satu cabang di dalam rumpun hukum internasional publik yang mengalami perkembangan pesat selepas Perang Dunia II adalah hukum pidana internasional. Perkembangan cabang ilmu hukum ini ditandai oleh pembentukan mahkamah-mahkamah pidana militer yang bersifat internasional di Nurnberg dan di Tokyo. Mahkamah Militer Internasional Nurnberg dibentuk berdasarkan Piagam London tanggal 8 Agustus 1945 dan dimaksudkan untuk mengadili individu-individu yang dianggap paling bertanggungjawab atas terjadinya kejahatan-kejahatan berat yang dilakukan oleh rezim Nazi Jerman menjelang dan selama berlangsungnya Perang Dunia II. Sementara itu, Mahkamah Militer Internasional untuk Timur Jauh yang dibentuk di Tokyo sebagai implemantasi dari Deklarasi Postdam tanggal 26 Juli 1945 juga dilandasi oleh tujuan yang sama, yakni untuk melakukan proses pemidanaan terhadap individu-individu dalam rezim Kekaisaran Jepang yang dianggap bertanggungjawab melakukan kejahatan-kejahatan serius dalam Perang Dunia II, khususnya di front Asia-Pasifik.

Ada pro dan kontra berkaitan dengan pembentukan dan aktivitas Mahkamah Militer Internasional Nurnberg dan Tokyo. Mereka yang pro menyatakan bahwa pembentukan kedua lembaga pengadilan yang bersifat internasional tersebut merupakan sebuah langkah progresif untuk memastikan bahwa setiap orang yang dianggap bertanggungjawab melakukan kejahatan-kejahatan serius yang terkait dengan Perang Dunia II pada akhirnya menerima konsekuensi hukum yang setimpal, berupa penjatuhan pidana. Langkah ini dipandang progresif karena secara tegas meninggalkan paradigma tradisional di dalam hukum internasional yang sebelumnya memfokuskan diri pada negara, bukan individu, sebagai subyek hukum yang dapat dikenai konsekuensi hukum. Pandangan ini juga dirasa masuk akal, karena ada kesulitan-kesulitan yang dihadapi ketika proses hukum terhadap para pelaku kejahatan serius itu hendak dilakukan secara konservatif melalui mekanisme domestik. Satu hal yang jelas, sistem hukum domestik Jerman dan Jepang yang sudah hancur ketika itu dipandang tidak mungkin bisa dimanfaatkan untuk mengadili para pelaku kejahatan berat, sehingga pembentukan sebuah pengadilan ad hoc yang bersifat internasional dianggap sebagai langkah yang rasional. Di sisi lain, mereka yang kontra terhadap kedua mahkamah tersebut mengemukakan argumen politis bahwa kedua pengadilan yang memiliki karakteristik internasional tersebut hanya merupakan forum politis bagi negara-negara pemenang perang untuk membalas dendam terhadap musuhmusuh mereka dengan cara yang elegan. bagi mereka yang kontra, proses yang berlangsung di mahkamah Militer Internasional Nurnberg dan Tokyo tidak lebih dari sekedar sandiwara yang pada akhirnya bermuara pada penerapan keadilan retributif versi pemenang perang (victor's justice). 
Terlepas dari pro dan kontra yang muncul, tidak dapat dipungkiri bahwa pembentukan kedua mahkamah militer internasional di Nurnberg dan Tokyo itu telah memberikan kontribusi yang tidak kecil bagi perkembangan sebuah cabang ilmu baru di bawah hukum internasional, yaitu hukum pidana internasional. Salah satu fondasi yang diletakkan secara cukup kokoh oleh mahkamah-mahkamah militer internasional pasca-berakhirnya Perang Dunia II tersebut adalah konseptualisasi kejahatan internasional (international crimes) sebagai perbuatan pidana yang menjadi fokus utama hukum pidana internasional. Pada masa Mahkamah Nurnberg, pada dasarnya ada tiga kategori perbuatan yang digolongkan sebagai kejahatan internasional, yaitu kejahatan terhadap perdamaian (crimes against peace), kejahatan terhadap kemanusiaan (crimes against humanity) dan kejahatan perang (war crimes). Dalam perkembangannya, konsep kejahatan terhadap perdamaian mengerucut pada satu jenis kejahatan internasional yang sekarang disebut sebagai kejahatan agresi (crimes of aggression), sedangkan kejahatan terhadap kemanusiaan kemudian terpecah menjadi dua kategori, karena genosida sebagai suatu bentuk kejahatan terhadap kemanusiaan yang bersifat khas dipandang sebagai satu kategori tersendiri. Istilah 'genosida' sendiri tidak ditemukan di dalam Piagam London 1945, karena istilah tersebut baru ditemukan dan dipublikasikan beberapa saat sebelumnya, yaitu pada tahun 1944 oleh seorang ahli hukum berkebangsaan Yahudi Polandia yang bernama Raphael Lemkin.

Cakupan konsep kejahatan internasional perlu ditegaskan untuk membedakannya dengan kejahatan transnasional (transnational crimes) yang sekarang lebih sering dipakai untuk merujuk pada kejahatan menurut hukum pidana domestik yang memiliki aspek lintas-batas negara. Meskipun beberapa sarjana pada awalnya menganggap bahwa dua istilah tersebut ('kejahatan internasional' dan 'kejahatan transnasional') sama dan bisa saling menggantikan, seiring dengan kristalisasi konsep kejahatan internasional dalam kerangka perkembangan disiplin hukum pidana internasional kini istilah 'kejahatan internasional' sudah terdefinisikan secara lebih spesifik dan dibedakan dari 'kejahatan transnasional.' Fenomena ini antara lain dikemukakan oleh Robert Cryer yang mengatakan:

Until the establishment of the international courts and tribunals in the 1990s, the concept of international criminal law tended to be used to refer to those parts of a state's domestic criminal law which deal with transnational crimes, that is, crimes with actual or potential transborder effects. ${ }^{1}$

Pembedaan antara hukum yang mengatur kejahatan transnasional dan hukum yang mengatur kejahatan internasional ternyata juga tercermin

Robert Cryer, et.al., An Introduction to International Criminal Law and Procedure (Cambridge University Press 2010) 5-6. 
dalam istilah-istilah berbeda yang dipergunakan di berbagai negara. Sebagai contoh, dalam bahasa Jerman dikenal istilah 'völkerstrafrecht' yang berbeda dari 'internationales strafrecht'. Istilah 'völkerstrafrecht' dipergunakan untuk makna yang sempit dari hukum pidana internasional, yang mencakup kejahatan-kejahatan berikut: (a) der Völkermord (genosida); (b) die Verbrechen gegen die Menschlichkeit (kejahatan terhadap kemanusiaan); (c) die Kriegsverbrechen (kejahatan perang); dan (d) das Verbrechen der Aggresion (kejahatan agresi). ${ }^{2}$ Paralel dengan itu, dalam bahasa Perancis dikenal istilah 'droit international pénal' yang berbeda dari 'droit pénal international', dan dalam bahasa Spanyol dikenal istilah 'derecho internacional penal' yang tidak sama dengan 'derecho penal internacional.'3

Sekarang, khususnya setelah tahun 1990-an saat dua mahkamah kejahatan internasional ad hoc pasca-NurnbergTokyo dibentuk (ICTY untuk bekas Yugoslavia dan ICTR untuk Rwanda), konsep kejahatan internasional dipahami secara luas mencakup empat jenis perbuatan, yaitu: genosida (genocide); kejahatan terhadap kemanusiaan (crimes against humanity); kejahatan perang (war crimes); kejahatan agresi (crimes of aggression). Keempat jenis perbuatan tersebut dikategorikan sebagai kejahatan internasional karena sumber hukum bagi pengaturan terhadap perbuatan-perbuatan itu lebih didominasi oleh sumber-sumber hukum internasional, terutama perjanjian internasional (international treaties), daripada sumber-sumber hukum nasional.

Meski demikian, kecuali untuk kejahatan agresi, sesungguhnya inti dari genosida, kejahatan terhadap kemanusiaan dan kejahatan perang juga dapat ditemukan dalam sumber-sumber hukum nasional, khususnya dalam ketentuan-ketentuan hukum pidana domestik yang mengatur tentang pembunuhan dan penganiayaan. Tetapi, pembunuhan atau penganiayaan yang dilakukan dalam konteks kejahatan internasional harus dipandang sebagai kejahatan luar biasa (extra-ordinary crimes) yang terkadang tidak memadai untuk ditangani oleh infrastruktur hukum nasional.

Penanganan Kejahatan Internasional

Hukum pidana nasional maupun hukum pidana internasional yang berfokus pada kejahatan internasional sesungguhnya memiliki kesamaan dalam hal keduanya menjadikan individu sebagai subjek hukum yang dapat dimintai pertanggungjawaban atas perbuatan pidana yang dilakukan. Lebih lanjut, kalau individu menjadi subjek hukum pidana nasional dan hukum pidana internasional, forum manakah yang kemudian berwenang mengadili seorang pelaku kejahatan internasional? Hal ini menjadi lebih rumit karena sebagian besar kejahatan internasional sebenarnya juga tercakup

2 Christina Möller, 'Gerhard Werle, Völkerstrafrecht (International Criminal Law): Book Review' (2004) 5 German Law Journal 425, 427.

Robert Cryer, et.al., Op.Cit. 6. 
dalam pengaturan hukum pidana nasional, baik melalui ratifikasi atas instrumen hukum internasional yang relevan, atau murni mucul dari ranah norma hukum pidana domestik. Sebagai misal, salah satu wujud dari genosida adalah pembunuhan terhadap sekelompok orang atas dasar alasan kesukuan, ras, agama atau kebangsaan.

Meski memiliki atribut elemen yang khas, tindakan seseorang membunuh orang lain pada dasarnya sudah terakomodasi di dalam hukum pidana domestik negara-negara dalam kategori tindak pidana pembunuhan (murder). Baik tindak pidana pembunuhan dengan genosida yang berwujud pembunuhan atas sekelompok orang pada intinya memiliki elemen yang sama: penghilangan nyawa orang lain. Jika demikian, dapatkah pelaku genosida dalam bentuk pembunuhan terhadap sekelompok orang diadili di depan pengadilan nasional dan bukan di forum pengadilan internasional?

Pada dasarnya tidak tertutup kemungkinan bagi kejahatan internasional untuk diadili di depan pengadilan nasional. Namun, beberapa catatan penting perlu dikemukakan. Genosida, kejahatan terhadap kemanusiaan, kejahatan perang dan kejahatan agresi dikategorikan sebagai kejahatan internasional karena kejahatan-kejahatan tersebut dianggap sebagai kejahatan yang paling serius, sehingga memerlukan langkah serius dan luar biasa juga untuk mencegah dan menindak. Posisi ini tercermin secara jelas dalam konsiderans mukadimah
Statuta Roma 1998 yang menyebutkan: “...the most serious crimes of concern to the international community as a whole must not go unpunished and that their effective prosecution must be ensured by taking measures at the national level and by enhancing international cooperation." Kutipan tersebut menunjukkan secara jelas bahwa penindakan terhadap kejahatan internasional dapat dilakukan pada ranah nasional, namun diperlukan juga kerjasama internasional.

Dalam praktik, terkadang tidak mudah untuk mengandalkan mekanisme dan lembaga hukum nasional untuk menangani situasi kejahatan internasional. Kejahatan internasional dapat dilakukan oleh individu yang secara politik memiliki kekuasaan di suatu negara, sehingga pengadilan nasional yang diharapkan menindak dan menangani kejahatan internasional yang dilakukan bisa berada dalam situasi tidak mampu melakukan fungsi yang diharapkan (expected role) yang semestinya. Kalau ini dibiarkan, pelaku kejahatan internasional tentu saja akan menikmati kebebasan dari jangkauan hukum, yang dalam diskursus tentang Hak Asasi Manusia dikenal dengan istilah impunitas (impunity). Ketika hal tersebut terjadi, mekanisme internasional diperlukan guna memastikan agar pelaku kejahatan internasional tidak dibiarkan bebas tanpa tersentuh hukum.

Untuk membahas persoalan apakah norma-norma hukum pidana internasional (khususnya yang 
berkaitan dengan kejahatan internasional), dapat diadili di forum pengadilan pidana nasional suatu negara, terlebih dahulu perlu dikemukakan apakah norma-norma hukum pidana internasional terdapat di dalam sistem norma hukum pidana nasional dan dapat diterapkan oleh pengadilan nasional. Pada dasarnya ada dua kemungkinan terkait dengan keberadaan norma-norma hukum pidana internasional di dalam hukum nasional. Kemungkinan pertama, norma-norma hukum pidana internasional ada dan menjadi bagian dari sistem hukum pidana nasional, karena suatu negara sudah meratifikasi instrumen hukum internasional yang mengatur tentang kejahatan internasional. Kemungkinan kedua, tanpa secara formal meratifikasi perjanjian internasional, hukum nasional suatu negara mengembangkan sendiri norma-norma hukum pidana internasional.

Norma-norma hukum pidana internasional dapat menjadi bagian dari sistem norma hukum pidana nasional negara-negara melalui proses ratifikasi. Ratifikasi sendiri pada dasarnya adalah tindakan formal dari suatu negara untuk mengikatkan diri pada sebuah perjanjian internasional. Melalui ratifikasi, suatu negara menunjukkan itikadnya untuk tunduk pada kewajiban-kewajiban yang digariskan dalam perjanjian internasional yang diratifikasi. Dengan demikian, ketika sebuah perjanjian internasional menghendaki pemberlakuan normanorma tertentu dalam lingkup jurisdiksi hukum nasional negara yang telah mengikatkan diri terhadap perjanjian internasional, negara tersebut memiliki kewajiban hukum untuk memberlakukan norma-norma hukum yang terkandung di dalam perjanjian internasional. Oleh karena itu, ketika suatu negara meratifikasi Statuta Roma 1998, secara prinsip ia terikat pada substansi norma-norma yang ada di dalam Statuta Roma. Demikian juga halnya dengan perjanjian-perjanjian internasional lain yang berkaitan dengan kejahatan internasional, seperti Genocide Convention 1948 dan Geneva Conventions 1949.

Di antara keempat jenis kejahatan internasional, genosida dan kejahatan perang yang sudah cukup baik terkodifikasi dalam perjanjian internasional yang dapat diratifikasi oleh negara-negara. Sementara itu, kejahatan terhadap kemanusiaan dan kejahatan agresi belum banyak terakomodasikan dalam instrumen hukum internasional yang memiliki kekuatan mengikat. Hal ini wajar, mengingat bahwa genosida dan kejahatan perang relatif telah mencapai kematangan konseptual dibanding kejahatan terhadap kemanusiaan dan kejahatan agresi yang perkembangan konsepnya cenderung lambat.

Saat ini sudah ada 142 negara yang menyatakan mengikatkan diri terhadap Konvensi Genosida 1948. Artikel 4 Konvensi Genosida 1948 memuat ketentuan bahwa setiap orang yang melakukan genosida harus dihukum, biarpun mereka adalah pemimpin yang secara konstitusional bertanggung 
jawab, pejabat publik ataupun individu. Melengkapi Artikel 4, Artikel 5 dari konvensi tersebut mewajibkan negaranegara pihak Konvensi Genosida 1948 untuk membuat legislasi nasional yang diperlukan untuk melaksanakan ketentuan-ketentuan konvensi, khususnya untuk menghukum pelaku genosida. Ketentuan ini yang menjadi pintu masuk bagi norma-norma hukum pidana internasional yang terdapat di dalam perjanjian internasional untuk masuk ke dalam sistem norma hukum pidana nasional negara-negara yang terikat pada Konvensi Genosida 1948. Sebagian besar didorong oleh kewajiban konvensi, saat ini ada lebih dari 80 negara yang sudah memiliki pengaturan tentang genosida di dalam sistem hukum nasional mereka. ${ }^{4}$

Hal yang sama juga terjadi dengan kejahatan perang yang sebagian besar bersumber dari Konvensi-konvensi Jenewa 1949. Konvensi-konvensi Jenewa 1949 antara lain memuat kewajiban agar negara-negara pihak dari konvensi-konvensi ini membuat legislasi nasional guna memastikan bahwa pelaku pelanggaran berat (grave breaches) terhadap ketentuan-ketentuan konvensi dihukum atau diserahkan kepada negara lain yang berwenang mengadili dan menghukum. ${ }^{5}$ Ketentuan inilah yang menjadi titik-taut antara norma hukum pidana internasional yang terkandung di dalam konvensi internasional (Konvensi-konvensi Jenewa 1949) dengan sistem hukum domestik negara-negara.

Selain melalui ratifikasi atau instrumen pengikatan diri lain, substansi norma-norma hukum pidana internasional juga dapat terkandung di dalam sistem norma hukum pidana nasional karena hal lain. Suatu negara memiliki kebebasan untuk mengembangkan substansi normatif dalam sistem hukum nasional mereka, termasuk mengadopsi norma-norma hukum negara lain atau norma hukum internasional tanpa perlu meratifikasi instrumen hukum internasional. Hal ini misalnya terjadi dengan Indonesia, yang di satu sisi (ketika tulisan ini disusun) belum mengikatkan diri pada Statuta Roma 1998, namun di sisi lain sudah memasukkan sebagian substansi Statuta Roma 1998 ke dalam hukum nasionalnya, yaitu dalam Pasal 8 dan Pasal 9 Undang-Undang No. 26 Tahun 2000 tentang Pengadilan Hak Asasi Manusia. ${ }^{6}$

Joseph Rikhof, penasehat senior pada Crimes against Humanity and War

Anonim, 'Implementing the Genocide Convention in Domestic Law' <http:// www.preventgenocide.org/law/domestic/> diakses 5 Agustus 2015.

Lihat Artikel 49 Konvensi Jenewa I, Artikel 50 Konvensi Jenewa II, Artikel 129 Konvensi Jenewa III, dan Artikel 146 Konvensi Jenewa IV. Secara konseptual sebenarnya ada perbedaan antara "kejahatan perang" dengan "pelanggaran berat terhadap Konvensi-konvensi Jenewa 1949." Kejahatan perang sejak awal muncul dalam ranah norma-norma hukum internasional, sementara "pelanggaran berat" cenderung diserahkan kepada jurisdiksi nasional berdasarkan Konvensi-konvensi Jenewa 1949. Namun, dalam Artikel 85 (5) Protokol Tambahan I (1977), ditegaskan bahwa pelanggaran berat termasuk kejahatan perang. Lihat Marko Divac Öberg, 'The Absorption of Grave Breaches Into War Crimes Law' (2009) 91 International Review of the Red Cross 163, 163 dan 167. 
Section Departemen Kehakiman Kanada mengemukakan ada 4 pola dalam praktik negara-negara untuk menerapkan jurisdiksinya terhadap individu-individu yang dianggap melakukan pelanggaran berat, termasuk kejahatan internasional. Pertama, suatu negara dapat menerapkan prinsip jurisdiksi ekstrateritorial yang digabungkan dengan norma substantif tindak pidana umum (misalnya pembunuhan, penganiayaan) dan kemudian disertai dengan pemidanaan yang diperberat. Jadi, dalam pola pertama ini negara mengandalkan norma hukum pidana nasional umum yang dikombinasikan dengan pemberatan pidana untuk diterapkan pada kejahatan internasional. Sebagai contoh, terhadap pelaku genosida dapat diterapkan pasal hukum pidana umum tentang pembunuhan, yang kemudian disertai dengan penjatuhan pidana yang lebih berat daripada sekedar pembunuhan biasa. Pola ini antara lain dipergunakan oleh Denmark dan Norwegia. ${ }^{7}$

Pola kedua disebut sebagai "implementasi statis." Menurut pola ini, norma hukum nasional mengutip ulang rumusan kejahatan internasional yang ada di dalam instrumen hukum internasional (Statuta Roma 1998). Ada 3 variasi untuk pola ini. Pertama, hukum nasional mengutip secara persis rumusan yang ada di dalam instrumen hukum internasional (Inggris, Malta,
Yordania). Kedua, hukum nasional tidak secara lengkap mengutip formulasi redaksional instrumen hukum internasional, melainkan hanya merujuk pada instrumen hukum internasional yang relevan (Selandia Baru, Afrika Selatan, Uganda, Kenya). Ketiga, hukum nasional tidak hanya mengutip ketentuan yang ada di dalam instrumen hukum internasional, melainkan mengutip pula penjelasan yang lebih rinci yang ada di dalam dokumen pelengkap instrumen hukum internasional, misalnya dokumen "Element of Crimes" yang melengkapi Statuta Roma 1998 (Australia).

Pola ketiga, yang oleh Joseph Rikhof disebut sebagai "model dinamis," merujuk pada mekanisme di mana ketentuan-ketentuan yang ada di dalam instrumen hukum internasional diformulasikan ulang dalam sistem hukum pidana nasional dengan tujuan untuk memperjelas konsep-konsep dalam instrumen hukum internasional yang dianggap kabur. Pola ini antara lain diterapkan oleh Jerman, Belanda, Uruguay, Argentina dan Ekuador.

Pola keempat, yang juga disebut sebagai "model hibrida" antara lain dianut oleh Kanada, Costa Rica dan Finlandia. Berdasarkan pola ini, hukum pidana nasional menguraikan sebagian tindak pidana yang termasuk kejahatan internasional, namun untuk sebagian

Pasal 8 mengatur tentang genosida, sedangkan Pasal 9 Undang-Undang Nomor 26 Tahun 2000 tentang Pengadilan HAM mengatur tentang kejahatan terhadap kemanusiaan.

Joseph Rikhof, 'Fewer Places to Hide? The Impact of Domestic War Crimes Prosecutions on International Impunity' (unpublished paper, ttp., tth.) 9. 
lagi hukum pidana nasional hanya merujuk pada instrumen hukum internasional. ${ }^{8}$

Dengan pola-pola seperti itu, pada dasarnya pengadilan nasional negaranegara memiliki kapabilitas untuk menangani perkara-perkara yang bersubstansi kejahatan internasional. Meskipun demikian, sulit untuk memungkiri kenyataan bahwa dalam kasus-kasus tertentu, penegakan norma-norma hukum pidana internasional melalui forum pengadilan nasional terkadang mengalami hambatan yang tidak mudah, khususnya kalau kejahatan itu dilakukan oleh figur-figur yang secara faktual masih memiliki kekuasaan politik atau militer, atau terafiliasi dengan kekuasaan politik atau militer di suatu negara. Ketika penegakan hukum di forum pengadilan nasional menghadapi situasi seperti itu, ada berbagai pertimbangan (terutama pertimbangan politik) yang kemudian bermuara pada ketidakmampuan (inability) atau ketidakmauan (unwillingness) pengadilan nasional. Hambatan ini bisa berupa kekuatiran tentang independensi hakim, kesulitan untuk mendapatkan saksi dan bukti, sampai bayang-bayang kerusuhan dan perang saudara.

Pada saat tulisan ini disusun, terjadi sebuah perkara hukum yang menarik di Guatemala, yang bisa membantu memberikan ilustrasi yang lebih jelas tentang kendala-kendala legal maupun ekstra legal yang dapat menghambat penegakan hukum terhadap pelaku kejahatan internasional dengan menggunakan sistem hukum nasional. Perkara tersebut melibatkan Efrain Rioss Mont, mantan presiden Guatemala. Rios Montt adalah seorang jenderal angkatan darat Guatemala yang menjadi penguasa Guatemala melalui kudeta militer pada tanggal 23 Maret 1982. Untuk menghadapi kelompok gerilyawan yang menentangnya, Rios Montt menggunakan kekerasan dan menerapkan prinsip Frijoles y Fusiles (secara harafiah berarti "senapan dan kacang." Berdasarkan prinsip ini, Montt akan memberikan makanan bagi kelompok masyarakat yang membantunya melawan pemberontak, dan akan menindas kelompok yang membantu gerilyawan. Kelompok Indian Maya Ixil secara khusus mengalami penindasan secara kejam karena kelompok ini disangka sering memberikan perlindungan dan bantuan bagi gerilyawan. Operasi militer melawan gerilyawan ini menyebabkan hancurnya ratusan desa, dan bahkan dalam satu kejadian, kurang lebih 250 warga sipil tewas. Secara keseluruhan, ribuan penduduk sipil tewas semasa Montt memegang kekuasaan de facto di Guatemala. Satu tahun berikutnya, ia ganti dikudeta oleh Óscar Humberto Mejía Victores, Menteri Pertahanannya sendiri.

Sejak tahun 2007 Montt menjadi anggota kongres Guatemala dan karena jabatannya itu ia menikmati kekebalan hukum. Ketika jabatannya sebagai 
anggota kongres berakhir pada tanggal 14 januari 2012, ia juga kehilangan imunitas hukumnya. Pada tanggal 26 Januari 2012 ia secara resmi didakwa melakukan genosida dan kejahatan terhadap kemanusiaan yang terjadi saat ia memegang kekuasaan pada tahun 1982-1983. ${ }^{9}$ Selanjutnya pemeriksaan di pengadilan mulai diselenggarakan pada tanggal 19 Maret 2013, namun pada tanggal 19 April 2013 Mahkamah Agung Guatemala mengeluarkan perintah agar pemeriksaan pengadilan ditunda. Perintah tersebut dikeluarkan atas dasar permintaan Otto Perez Molina, Presiden Guatemala petahana, setelah namanya disebut-sebut dalam kesaksian pengadilan sebagai orang yang juga turut serta dalam kekejaman yang dilakukan rezim Rios Montt. Mengingat sebagai presiden petahana Otto Perez Molina memiliki kekebalan (imunitas), hakim memerintahkan agar proses persidangan diulangi lagi dari proses yang sudah terjadi pada bulan November 2011, tanpa melibatkan Molina.

Pada tanggal 10 Mei 2013, Rios Montt dinyatakan bersalah melakukan genosida serta kejahatan terhadap kemanusiaan dan dijatuhi pidana penjara selama 80 tahun. Ia menjadi mantan kepala negara pertama yang dijatuhi pidana di negaranya sendiri karena dakwaan genosida. Namun, pada tanggal 20 Mei 2013 Mahkamah Konstitusi Guatemala membatalkan putusan tersebut. Mahkamah Konstitusi Guatemala membatalkan putusan itu terkait dengan ketidaksepakatan di antara para hakim pada bulan April 2013 tentang forum pengadilan yang berwenang mengadili perkara Montt. ${ }^{10}$ Putusan Mahkamah Konstitusi Guatemala ini menuai banyak kritik pedas dari pihak-pihak yang menganggap bahwa putusan tersebut hanyalah upaya untuk meloloskan Montt dari jerat pidana.

Perkara Rios Montt jelas memiliki implikasi politik. Ketika tindakan yang didakwakan kepada Rios Montt terjadi, Presiden Guatemala petahana, Otto Perez Molina, adalah seorang mayor angkatan darat di wilayah Indian Maya Ixil. Posisi ini tentu memunculkan isu politik yang kental. Bagaimanapun, selain masih menikmati kekebalan sementara sebagai presiden, Otto Perez Molina sendiri selaku purnawirawan perwira tinggi angkatan bersenjata Guatemala masih memiliki kekuasaan dan pengaruh yang kuat dalam politik Guatemala. Dalam kaitan ini, Naomi Roht-Arriaza, seorang guru besar hukum dari University of California mencatat bahwa pendakwaan atas Rios Montt telah menimbulkan polarisasi politik di Guatemala. Kelompok purnawirawan perwira militer Guatemala menuduh bahwa dakwaan tersebut merupakan hasil konspirasi politik gereja, pemerintah AS dan negara-negara Eropa. Tuduhan tersebut juga diikuti ancaman dari organisasiorganisasi swasta yang menentang

\footnotetext{
Kate Doyle, 'Justice in Guatemala' (2012) 45 NACLA Report on the Americas 37, 37.

‘Guatemala's Top Court Annuls Rios Montt Genocide Conviction’ (Reuters, 21 Mei 2013).
} 
proses hukum terhadap Montt untuk melumpuhkan pemerintah. ${ }^{11}$

Kasus Guatemala di atas secara jelas menunjukkan bahwa dalam situasi tertentu pengadilan nasional tidak dapat diandalkan untuk menegakkan normanorma hukum pidana internasional. Perangkat hukum dan pengadilan nasional juga dapat terjebak dalam situasi ketidakmampuan (unability), misalnya dalam kasus di mana suatu negara mengalami kehancuran institusional yang juga merusakkan institusi-institusi penegak hukumnya. Situasi seperti ini misalnya terjadi dengan Jerman setelah negara ini mengalami kehancuran dalam Perang Dunia II.

Selain ketidakmampuan yang bersifat objektif, pengadilan nasional suatu negara juga secara subjektif dapat merefleksikan keengganan atau bahkan ketidakmauan (unwillingness) untuk mengadili pelaku kejahatan internasional. Kasus Rios Montt dapat dikategorikan dalam kondisi ini, karena meskipun proses pengadilan digelar, namun di dalamnya ada manuvermanuver hukum yang merefleksikan keengganan pengadilan untuk memeriksa dan menjatuhkan pidana terhadap tersangka. Keengganan pengadilan nasional untuk mengadili dapat tampak dari absennya inisiatif negara (aparat penegak hukum) untuk memulai prosekusi. Namun, ada pula bentuk lain keengganan pengadilan untuk mengadili pelaku kejahatan internasional, yakni dengan melakukan poses pengadilan "setengah hati” yang tidak benar-benar dimaksudkan untuk menghasilkan keadilan, melainkan hanya untuk membangun citra positif pemerintah.

Kekurangan dalan pengadilan nasional yang berupa inability maupun unwillingness ini yang juga menjadi alasan bagi munculnya penegakan hukum pidana internasional alternatif, yaitu melalui pengadilan-pengadilan hibrida dan pengadilan internasional. Namun, harus diakui bahwa pembentukan pengadilan/mahkamah yang murni memiliki karakteristik internasional tidaklah mudah. Selain membutuhkan biaya yang tidak sedikit, konstelasi politik internasional juga bisa menjadi hambatan serius bagi terwujudnya mahkamah kejahatan yang bersifat internasional. Oleh karena itu, pembentukan pengadilan-pengadilan hibrida merupakan sebuah alternatif yang sebenarnya juga bisa ditempuh untuk menegakkan hukum dalam kasus-kasus kejahatan internasional.

\section{Dasar Pembentukan "Pengadilan Hibrida"}

Pengertian Pengadilan Hibrida

Pada akhir dasawarsa 1990-an dunia menyaksikan munculnya lembaga-lembaga pengadilan kriminal yang dikategorikan sebagai pengadilan hibrida (hybrid courts), yang disebut sebagai pengadilan internasional generasi ketiga setelah Mahkamah

11 American Society of International Law - ASIL, 'Genocide and War Crimes in National Courts: the Conviction of Rios Montt in Guatemala and its Aftermath' (2013) 17 Insight. 
Militer Internasional Nurnberg dan Tokyo (generasi pertama) serta ICTY dan ICTR (generasi kedua).

Istilah "pengadilan hibrida" dipergunakan untuk menunjuk pada lembaga-lembaga pengadilan yang melibatkan unsur-unsur nasional maupun internasional di dalam penyusunan, struktur dan fungsinya serta dalam penerapan hukum dan prosedur pengadilan. ${ }^{12}$ Pengadilan hibrida jelas berbeda dari pengadilan nasional, karena secara eksplisit ia mengandung elemen internasional yang bisa berada pada struktur atau fungsinya. Ia juga berbeda dari pengadilan-pengadilan internasional karena ia mengakomodasikan elemenelemen hukum atau struktur hukum nasional di dalamnya. Hingga saat ini setidaknya ada 6 pengadilan yang dapat digolongkan sebagai pengadilan hibrida, yaitu:

a. The Serious Crimes Panels of the District Court of Dili (Timor Leste).

b. War Crimes Chamber in the State Court of Bosnia and Herzegovina), (Bosnia-Herzegovina).

c. "Regulation 64" Panels in the Courts of Kosovo (Kosovo).

d. The Extraordinary Chambers in the Courts of Cambodia (Kamboja).

e. The Special Court for Sierra Leone (Sierra Leone).

f. Special Tribunal for Lebanon (Lebanon).
Ada beberapa faktor yang melatarbelakangi pembentukan pengadilan-pengadilan hibrida. Pertamatama, kebutuhan pembentukan pengadilan-pengadilan hibrida pasti dilatarbelakangi oleh situasi yang memunculkan anggapan bahwa pengadilan nasional tidak dapat berfungsi secara ideal dalam konteks penegakan norma-norma hukum pidana internasional. Hal ini logis, mengingat bahwa ketika mekanisme hukum nasional dapat menjalankan fungsinya secara baik di dalam merespons kejahatan internasional dalam cakupan jurisdiksi mereka, pastilah forum penegakan hukum lain seperti pengadilan hibrida tidak diperlukan.

Seperti sudah dikemukakan, dalam keadaan tertentu pengadilan nasional tidak dapat diandalkan untuk merespons kejahatan internasional secara patut. Ada kalanya pengadilan nasional mengalami ketidakmampuan berfungsi ketika ia mengalami kerusakan struktur dan sistem. Kerusakan struktur dan sistem pengadilan nasional dapat terjadi pasca suatu negara dilanda konflik yang serius. Konflik bersenjata yang mengikuti peristiwa pecahnya (dismemberment) negara Yugoslavia pada paruh pertama dekade 1990-an merupakan salah satu contoh yang menunjukkan bagaimana struktur pengadilan nasional tidak dapat lagi diandalkan. Demikian juga halnya

12 Kai Ambos dan Mohammed Othman, dikutip dalam Eileen Skinnider, 'Experiences and Lessons from "Hybrid" Tribunals: Sierra Leone, East Timor and Cambodia' (Symposium on the International Criminal Court, Beijing, Pebruari 2007) 1. 
dengan situasi perang saudara di Rwanda yang mengakibatkan tidak dapat berfungsinya pengadilan nasional. Hal yang sama juga terjadi dengan Sierra Leone dan Timor Leste yang pengadilan nasionalnya tidak mampu menjalankan fungsi sebagaimana mestinya karena keruntuhan struktur dan sistemnya.

Struktur dan sistem yang masih relatif utuh pun tidak selalu menjamin bahwa pengadilan nasional akan menjalankan fungsi sebagaimana diharapkan di dalam merespons kejahatan internasional. Kondisi ketidakmauan (unwillingness) ini dapat terjadi ketika pelaku kejahatan internasional yan harus diproses secara hukum di pengadilan nasional adalah figur yang berkuasa, baik secara politik maupun secara militer. Untuk keadaan seperti ini prosekusi pelaku kejahatan internasional oleh pengadilan nasional sebenarnya dimungkinkan, namun pengadilan nasional secara subjektif memilih untuk tidak melakukan prosekusi karena alasan-alasan tertentu yang umumnya berkaitan dengan faktor politik.

Dalam keadaan di mana sistem pengadilan nasional tidak dapat diandalkan untuk melakukan penegakan hukum terhadap pelaku kejahatan internasional, salah satu alternatif yang dapat ditempuh untuk mencegah terjadinya impunitas adalah dengan membentuk pengadilan kriminal yang bersifat internasional seperti halnya Mahkamah Militer Internasional
Nurnberg, Mahkamah Militer Internasional Tokyo, ICTY dan ICTR. Namun, pembentukan mahkamahmahkamah yang bersifat internasional tersebut juga membawa konsekuensikonsekuensi tertentu. Secara praktis, pembentukan dan operasionalisasi mahkamah yang bersifat internasional merupakan sebuah pekerjaan besar yang tidak selalu dapat dilakukan dengan mudah. Tentang ini Cryer mengatakan:

There are various reasons for avoiding resort to a new international tribunal. International institutions like the ICTY and the ICTR tend to be large and expensive; calls for similar tribunals have been unsuccessful. Their capacity is limited to a few cases and they have hitherto ben located away from the State in question for security or other reasons. $13^{13}$

Selain kesulitan yang bersifat praktis, pembentukan mahkamah yang bersifat internasional juga dapat memunculkan kesan bahwa pengadilan nasional tidak dianggap berkepentingan dengan proses prosekusi pelaku kejahatan internasional. Penjatuhan pidana yang dilakukan oleh mahkamah pidana yang bersifat internasional bisa jadi justru akan dianggap sebagai putusan yang arbitrer.

Untuk mengatasi kesulitankesulitan tersebut, salah satu alternatif lain yang dapat diambil adalah membentuk pengadilan hibrida, yang menggabungkan aspek-aspek positif

13 Robert Cryer, et.al., Op.Cit. 181. 
dari pengadilan pidana nasional dan pengadilan pidana internasional. Atas dasar itu, tujuan utama yang hendak dicapai oleh pengadilan-pengadilan hibrida pada hakikatnya adalah mewujudkan perdamaian dan keadilan berdasarkan standar hukum internasional dengan cara mengakhiri impunitas bagi pelaku kejahatan internasional, melalui keterlibatan komponen-komponen hukum nasional. Tujuan tersebut antara lain tercermin secara cukup jelas dalam konsiderans Resolusi Dewan Keamanan PBB No. 1315 (2000) yang memandatkan pembentukan pengadilan hibrida di Sierra Leone, yang pada satu bagian berbunyi:

... Recognizing that, in the particular circumstances of Sierra Leone, a credible system of justice and accountability for the very serious crimes committed there would end impunity and would contribute to the process of national reconciliation and to the restoration and maintenance of peace...

Dengan kalimat yang berbeda, MartinOrtega \& Herman mengatakan bahwa:

[h]ybrid tribunals fulfil one of the most important goals of transitional justice; to achieve justice after conflict through the prosecution of the perpetrators of the most serious violations of human rights. They also have the potential to interact with peacebuilding activities, particularly the promotion of rule of law and reform of the judicial sector and the justice system as a whole. ${ }^{14}$

Memang, khususnya di daerah-daerah yang baru berada dalam masa transisi pasca-konflik, ada kebutuhan yang unik di dalam merespons kejahatankejahatan berat yang terjadi semasa konflik masih berkecamuk. Di satu sisi, ada kebutuhan untuk mempertahankan situasi damai yang sudah terwujud. Di sisi yang lain, ada pula kebutuhan untuk mewujudkan keadilan melalui prosekusi terhadap mereka yang melakukan kejahatan-kejahatan berat semasa terjadi konflik.

Dua kepentingan yang berbeda ini tidak selalu dapat berjalan beriringan. Kebutuhan untuk menjaga perdamaian pasca-konflik sering kali dapat dipenuhi hanya dengan mengabaikan keadilan dan melupakan pemidanaan terhadap para pelaku kejahatan erat di masa lalu, karena penegakan hukum terhadap mereka mengandung risiko meletupnya kembali konflik yang sudah mereda. Sebaliknya, pengutamaan keadilan melalui penegakan hukum terhadap para pelaku kejahatan berat juga dapat mengorbankan kondisi damai yang barang kali berhasil dicapai dengan cara yang tidak mudah.

Situasi yang dikenal dengan istilah "peace - justice dilemma" ini memang tidak menghendaki pendekatan yang terlalu kaku dan didominasi oleh salah satu kepentingan. Situasi seperti ini memerlukan penanganan komprehensif yang umumnya dikemas dalam upayaupaya "peacebuilding". Dalam kerangka inilah, pengadilan hibrida memiliki karakteristik yang kompatibel dengan upaya-upaya peacebuilding karena beberapa alasan. Pertama, pengadilan

14 Olga Martin-Ortega dan Johanna Herman, 'Hybrid Tribunals \& the Rule of Law: Notes from Bosnia \& Herzegovina \& Cambodia' (2010) 7 JAD-PbP Working Paper Series 6. 
hibrida jelas pada dasarnya memberikan peran bagi sistem hukum nasional negara untuk ikut andil dalam proses mewujudkan keadilan. Keterlibatan komponen sistem hukum nasional dalam aktivitas penegakan hukum pada gilirannya akan mengembalikan kepercayaan diri dan kewibawaan sistem hukum nasional yang mengarah pada penguatan sistem hukum yang bersangkutan. Kedua, dalam situasi transisional pasca-konflik, tidak jarang pengadilan nasional terseret ke dalam pusaran politik yang dapat mendistorsi fungsi pengadilan selaku pemberi keadilan (justice dispenser). Ia bisa terdeviasi pada dua kutub pilihan yang berbeda, yakni menghukum ringan pelaku kejahatan berat (atau bahkan membebaskan tersangka pelaku), atau sebaliknya, ia juga bisa berubah menjadi ajang balas dendam terhadap mereka yang pernah melakukan kejahatan berat semasa konflik. Dalam dua situasi ini objektivitas pengadilan lah yang menjadi isu sentral. Namun, objektivitas pengadilan akan lebih dapat dijaga manakala ada komponen internasional yang turut terlibat dalam proses penegakan hukum dalam wujud pengadilan hibrida.

\section{Pola-pola Pembentukan Pengadilan Hibrida}

Meskipun pada intinya dalam setiap pengadilan hibrida dapat ditemukan campuran antara elemen sistem pengadilan nasional dan elemen sistem pengadilan internasional, latar belakang dan dasar hukum pembentukan pengadilan-pengadilan hibrida berbeda.
Dari sisi latar belakang, beberapa pengadilan hibrida muncul dari situasi konflik sipil yang disertai oleh penindasan oleh penguasa, seperti di Sierra Leone dan Kamboja. Sementara itu, pengadilan hibrida di BosniaHerzegovina, Kosovo dan Timor Leste dilatarbelakangi oleh konflik untuk memerdekakan diri, dan pengadilan hibrida di Lebanon dibentuk sebagai respons atas pembunuhan politik yang berpotensi mengganggu keamanan dan perdamaian regional.

Selain latar belakang politik yang berbeda-beda, dasar hukum bagi pembentukan pengadilan-pengadilan hibrida juga berlainan. Dilihat dari dasar hukum pembentukannya, dapat diidentifikasi adanya tiga kategori pengadilan hibrida, yaitu pengadilan hibrida yang dibentuk berdasarkan perjanjian antara PBB dengan negara, pengadilan hibrida yang dibentuk oleh PBB atau pemerintahan internasional (international administration) di suatu negara, dan pengadilan hibrida yang dibentuk oleh suatu negara namun mendapatkan dukungan internasional.

Pengadilan Hibrida yang Dibentuk Berdasarkan Perjanjian antara PBB dengan Negara

Salah satu dasar hukum pembentukan pengadilan hibrida adalah perjanjian antara $\mathrm{PBB}$ dengan negara tertentu. Ada tiga pengadilan hibrida yang dibentuk dengan dasar perjanjian internasional semacam ini, yaitu the Extraordinary Chambers in the Courts of Cambodia, Special Court for Sierra Leone, dan Special Tribunal for Lebanon. 
The Extraordinary Chambers in the Courts of Cambodia dibentuk berdasarkan perjanjian antara pemerintah Kerajaan Kamboja dengan PBB pada tanggal 6 Juni 2003. Kesepakatan itu merupakan ujung dari proses panjang yang dimulai pada tahun 1997 ketika Perdana Menteri Bersama Kamboja mengirimkan surat kepada Sekjen PBB untuk meminta bantuan di dalam membentuk sebuah pengadilan yang untuk mengadili pemimpinpemimpin Khmer Merah yang dianggap bertanggungjawab atas berbagai kekejaman yang dilakukan selama Khmer Merah memegang kekuasaan di negara itu antara 1975-1979. Pada bulan Maret tahun 2006, Sekjen PBB menunjuk 7 orang hakim untuk menjalankan fungsi mengadili pucuk pimpinan tertinggi rezim Khmer Merah. Dua bulan berikutnya pemerintah Kamboja memberitahukan bahwa lembaga judisial negara itu telah menyetujui penunjukan 30 hakim Kamboja dan hakim PBB untuk yang kemudian diambil sumpahnya pada bulan Juli 2006.

Hingga kini the Extraordinary Chambers in the Courts of Cambodia telah memeriksa dan mengadili lima petinggi Khmer Merah yang didakwa melakukan berbagai kejahatan internasional (genosida, kejahatan terhadap kemanusiaan dan kejahatan perang) dan juga tindak pidana berdasarkan hukum Kamboja, yaitu Kang Kek Iew, Nuon Chea, Khieu Shampan, Ieng Sary dan Ieng Thirith.
Special Court for Sierra Leone dibentuk untuk merespons pelanggaran HAM berat dan kejahatan internasional yang terjadi di Sierre Leone (Afrika Barat) sejak awal dekade 1990-an. Ketika itu, Sierra Leone dilanda perang saudara ketika pemberontak Revolutionary United Front (RUF) yang antipemerintah masuk ke Sierra Leone dari negara tetangganya, Liberia. Pelanggaran-pelanggaran serius dilakukan oleh pihak-pihak yang bertikai, namun salah satu karakteristik yang menonjol dari perang saudara di Sierra Leone ini adalah maraknya penggunaan tentara anak-anak dan tindakan mutilasi terhadap penduduk sipil. Perang saudara itu sendiri dinyatakan resmi berakhir pada tahun 2002 setelah Inggris dan pasukan PBB melakukan intervensi.

Pada tanggal 12 Juni tahun 2000, Presiden Sierra Leone, Ahmad Tejan Kabbah bersurat kepada Sekjen PBB saat itu, Kofi Annan, untuk meminta agar masyarakat internasional membantu mengadili mereka yang disangka melakukan berbagai kekejaman selama berlangsungnya perang saudara di Liberia. Sebagai tindak lanjut dari proses tersebut, pada bulan Agustus tahun 2000 Dewan Keamanan PBB mengeluarkan Resolusi No. 1315 (2000) yang antara lain memberikan mandat kepada Sekjen PBB untuk memulai pembicaraan tentang pembentukan pengadilan khusus guna menangani kejahatan internasional di Sierra Leone khususnya yang berupa kejahatan kemanusiaan, kejahatan perang dan pelanggaran berat terhadap hukum humaniter internasional dan 
juga kejahatan lain di bawah hukum Sierra Leone, yang dilakukan di wilayah Sierra Leone. ${ }^{15}$

Pada tanggal 16 Januari 2002, Sekjen PBB dan pemerintah Sierra Leone menandatangani perjanjian pembentukan pengadilan khusus untuk Sierra Leone. Oleh Sekjen PBB Special Court for Sierra Leone itu disebut sebagai "a treaty-based suigeneris court of mixed jurisdiction and composition." 16 Sesuai dengan sistem ketatanegaraan Sierra Leone, negara itu kemudian meratifikasi perjanjian internasional tersebut dan Special Court for Sierra Leone mulai beroperasi sejak Juli 2002.

Pada tanggal 14 Pebruari 2005 Rafiq Hariri, Perdana menteri Lebanon saat itu, tewas terbunuh. Terhadap peristiwa tersebut Dewan Keamanan PBB membentuk sebuah komisi untuk membantu pemerintah Lebanon mengusut pembunuhan tersebut, termasuk mengungkap dugaan keterlibatan Syria, negara tetangga Lebanon. Lebanon kemudian memohon agar dientuk pengadilan internasional, dan Sekjen PBB ditugasi oleh Dewan Keamanan untuk berunding dengan Lebanon tentang kemungkinan pembentukan sebuah pengadilan yang memiliki sifat internasional. Sekjen PBB kemudian menyiapkan sebuah rancangan naskah perjanjian pembentukan pengadilan sebagaimana dimaksud, yang dilengkapi dengan statutanya. Meskipun pengadilan khusus untuk Lebanon ini dibentuk dengan cara yang hampir sama dengan pengadilan hibrida di Sierra Leone dan Kamboja, perlu dikemukakan bahwa ia tidak memiliki jurisdiksi atas kejahatan internasional (international crimes), melainkan hanya memiliki jurisdiksi yang terfokus pada peristiwa pembunuhan Hariri dan peristiwa serupa yang berkaitan. Oleh karena itu, pengadilan hibrida Lebanon ini tidak terlalu relevan dengan pembahasan tentang penegakan hukum pidana internasional.

Pengadilan Hibrida yang Dibentuk oleh PBB atau Pemerintahan Internasional (International Administration)

Selain dibentuk berdasarkan perjanjian internasional antara $\mathrm{PBB}$ dengan negara, pengadilan hibrida juga dapat dibentuk tanpa terlalu banyak melibatkan negara di mana pengadilan hibrida tersebut relevan. Langkah ini ditempuh mengingat bahwa negara yang bersangkutan mengalami konflik yang sedemikian parah, sehingga memerlukan kehadiran organ internasional untuk menjalankan fungsi pemerintahan sementara. Hal ini misalnya terjadi di Kosovo, Timor Leste dan Bosnia-Herzegovina.

Kosovo adalah nama sebuah daerah otonom yang berada di bawah Republik Serbia, salah satu negara bagian Republik Federasi Yugoslavia. Meski berada di bawah Republik Serbia, mayoritas etnis di Kosovo adalah Albania

15 UN Security Council No.S/RES/ 1315 (2000), butir $1 \& 2$.

16 UN Secretary General Report on the Establishment of a Special Court for Sierra Leone, UN Doc. S/2000/915 (4 Oktober 2000) par. 9. 
(sekitar 90\%). Ketegangan etnis, khususnya antara etnis Albania yang dimotori oleh Kosovo Liberation Army (KLA) dan pihak Yugoslavia beberapa kali terjadi di wilayah ini, termasuk ketika Perang Kosovo meletus pada tahun 1998. Setelah NATO melancarkan intervensi kemanusiaan mengikuti kegagalan perundingan dengan pihak Yugoslavia, perang di Kosovo dapat dihentikan dan pihak Yugoslavia menyerahkan pemerintahan di Kosovo kepada PBB sampai status yang definitif disepakati. Berdasarkan Resolusi Dewan Keamanan PBB No. 1244 (1999), PBB diberi kewenangan untuk menyelenggarakan pemerintahan sementara (interim administration) di Kosovo. Untuk itu, PBB kemudian membentuk UNMIK (United Nations Interim Administration Mission in Kosovo) dengan fungsi menjalankan kekuasaan eksekutif, legislatif dan juga kewenangan untuk menyelenggarakan peradilan. Pada saat UNMIK mulai menjalankan mandatnya di Kosovo, wilayah tersebut mengalami kehancuran infrastruktur dan masih dibayang-bayangi ketegangan antar etnik. Selain itu, Kosovo juga tidak memiliki tenaga legal yang memadai untuk menjalankan administrasi peradilan.

Di sisi lain, sepanjang berkaitan dengan kejahatan internasional, pada saat itu juga sudah ada ICTY, yang wilayah jurisdiksinya juga menjangkau Kosovo. Namun, prioritas penegakan hukum di Kosovo tampaknya berbeda dari fungsi yang diemban ICTY.
Karakteristik konflik di Kosovo dianggap berbeda dari wilayah lain di bekas Yugoslavia, sehingga tujuan yang hendak dicapai melalui penegakan hukum pun tidak sama dengan yang diharapkan dari ICTY.

Kebutuhan utama di Kosovo bukan semata-mata penegakan hukum yang tegas terhadap pelaku kejahatan internasional, melainkan lebih diarahkan pada terwujudnya hubungan damai di antara beragai kelompok yang bertikai, dan juga untuk mengupayakan penegakan hukum yang lebih luas cakupannya, tidak terbatas pada kejahatan internasional sebagaimana dicakup oleh ICTY. ${ }^{17}$

Pada awalnya yang digagas adalah pembentukan sebuah pengadilan khusus yang diberi sebutan Kosovo War and Ethnic Crimes Court yang berisi hakim-hakim internasional dan nasional. Namun, belakangan inisiatif ini dianggap terlampau mahal dan sensitif secara politik, sehingga akhirnya tidak direalisasikan. Sebagai gantinya, dibentuk sebuah pengadilan khusus yang diintegrasikan dalam sistem pengadilan biasa dengan komponen hakim dan penuntut internasional untuk menjaga ojektivitas pengadilan. Pengadilan khusus yang terintegrasi dengan pengadilan biasa itu dikenal dengan nama "Regulation 64 Panels", menunjuk pada instrumen hukum yang mendasari pembentukannya. 
Pada bulan Pebruari 2008, Republik Kosovo menyatakan kemerdekaan, dan sebagian fungsi UNMIK kemudian digantikan oleh institusi bentukan Uni Eropa, yaitu Eulex. Hampir sama seperti pengadilan hibrida Kosovo, pengadilan hibrida di Timor Leste juga dibentuk oleh administrasi sementara PBB pasca negara itu memilih memerdekakan diri dari Indonesia. Referendum yang menunjukkan kehendak mayoritas rakyat Timor Leste (saat itu masih bernama Timor Timur) untuk merdeka segera diikuti oleh kerusuhan yang melibatkan milisi antikemerdekaan. Kondisi itu memaksa Dewan Keamanan PBB mengambil langkah interventif melalui pengiriman pasukan Interfet (International Force for East Timor). Untuk menyelenggarakan pemerintahan sementara di Timor Leste, PBB membentuk UN Transitional Administration in East Timor (UNTAET) dengan mandat yang hampir sama dengan UNMIK di Kosovo. Untuk menjalankan fungsi pengadilan, khususnya terhadap kasus-kasus kejahatan serius yang terjadi pada tahun 1999, UNTAET membentuk the Serious Crimes Panels of the District Court of Dili berdasarkan UNTAET Regulation No. 2000/15 on the Establishment of Panels with Exclusive Jurisdiction over Serious Criminal Offences. Menurut Regulation No. 2000/15, kejahatan yang menjadi jurisdiksi Serious Crimes Panels adalah: (a) Genosida; (b) Kejahatan Perang; (c) Kejahatan terhadap Kemanusiaan; (d) Pembunuhan; (e) Kejahatan Seksual; dan (f) Penyiksaan. ${ }^{18}$

Sama seperti di Kosovo, di dalam Serious Crimes Panels terdapat hakim nasional dan hakim internasional. Menurut ketentuan Bagian 22 paragraf 22.1, majelis dalam Serious Crimes Panels terdiri dari 3 hakim dengan komposisi 2 hakim merupakan hakim internasional dan 1 hakim merupakan hakim nasional. Komposisi yang sama juga berlaku untuk tingkat banding.

Pengadilan hibrida lain yang dasar pembentukannya mirip dengan pengadilan hibrida di Kosovo dan Timor Leste adalah War Crimes Chamber in the State Court of Bosnia \& Herzegovina. Sama seperti Kosovo, wilayah BosniaHerzegovina sebenarnya secara teritorial dicakup juga oleh jurisdiksi ICTY. Namun, dipahami bahwa ICTY terutama dibentuk dalam situasi genting dan lebih difokuskan pada prosekusi terhadap tokoh-tokoh kunci dalam konflik Yugoslavia. Dengan demikian, di luar ICTY masih terdapat banyak pelaku kejahatan internasional yang belum terjangkau oleh hukum. Oleh karena itu, untuk membantu fungsi ICTY, sebuah pengadilan hibrida kemudian dibentuk di Bosnia-Herzegovina. ${ }^{19}$ Sama seperti di

18 UNTAET Regulation No. 2000/15, Section 1 paragraf 1.3.

19 Pembentukan War Crimes Chamber juga didorong oleh kebutuhan ICTY yang dibatasi oleh tenggat waktu yang diberikan oleh Dewan Keamanan PBB untuk menyelesaikan tugasnya, sehingga transfer perkara kepada War Crimes Chamber dianggap sebagai salah satu solusi seraya memperkuat kapasitas pengadilan nasional Bosnia-Herzegovina untuk mengadili kejahatan internasional dengan standar internasional pula. Lihat Bogdan Ivaniševiæ, 'The War Crimes Chamber in Bosnia and Herzegovina: From Hybrid to Domestic Court' (International Center for Transitional Justice 2008) 6. 
Kosovo dan Timor Leste, pengadilan hibrida ini juga diintegrasikan ke dalam pengadilan reguler Bosnia-Herzegovina dengan nama War Crimes Chamber. Pengadilan hibrida ini secara formal mulai beroperasi sejak tanggal 9 Maret 2005.

Pengadilan Hibrida yang Dibentuk oleh Suatu Negara namun Mendapatkan Dukungan Internasional

Selain kedua kategori yang telah diuraikan, ada pula kategori pengadilan hibrida yang sebenarnya dibentuk oleh suatu negara, kemudian mendapatkan asistensi dari masyarakat internasional. Namun, karena dibentuk oleh suatu negara, karakter hibridanyapun jauh lebih terbatas jika dibandingkan dengan dua kategori yang telah dibahas. Pengadilan yang masuk dalam kategori ini adalah War Crimes Chamber pada Pengadilan Distrik Beograd, Serbia. War Crimes Chamber yang menjadi satu dengan Pengadilan Distrik Beograd ini didirikan pada tahun 2003 dengan jurisdiksi mengadili kejahatankejahatan yang terjadi di bekas wilayah Yugoslavia. Pengadilan ini mulai berfungsi pada bulan Maret 2004. Kontribusi internasional dari pengadilan ini hanya terbatas pada dukungan yang diberikan oleh Amerika Serikat dan ICTY.

Manapun pola yang diterapkan, pada hakikatnya pengadilan hibrida merupakan gabungan antara komponen domestik pengadilan suatu negara dengan komponen internasional. Kondisi ini membuat pengadilan hibrida terpapar pada satu kelemahan yang tidak didapati dalam pengadilan/ mahkamah yang murni bersifat internasional, yaitu ketergantungan pada kehendak negara di mana pengadilan hibrida akan dibentuk. Pengadilan hibrida tidak akan mungkin dibentuk tanpa kehendak dan kerjasama negara terkait.

\section{PENUTUP}

Berdasarkan uraian di atas, dapat dikatakan bahwa secara umum pengadilan hibrida bisa menjadi alternatif penanganan kejahatan internasional, karena ia mengakomodasikan dua kepentingan yang berbeda, yakni kepentingan domestik dan kepentingan internasional. Komponen internasional yang ada di dalam pengadilan hibrida dapat diharapkan mampu mengurangi beban pengadilan nasional, baik beban historis maupun beban politis, sehingga komponen pengadilan hibrida dapat menjalankan fungsi secara lebih baik sebagaimana diharapkan.

Secara umum ada tiga pola yang diterapkan dalam pembentukan pengadilan-pengadilan hibrida, yaitu pengadilan hibrida yang dibentuk berdasarkan perjanjian antara PBB dengan negara, pengadilan hibrida yang dibentuk oleh PBB atau pemerintahan internasional (international administration) dan pengadilan hibrida yang dibentuk oleh suatu negara namun mendapatkan dukungan internasional. Dengan melihat pola-pola pembentukan pengadilan hibrida tersebut, tampak bahwa kehendak dan kerjasama dari negara di mana sebuah pengadilan 
hibrida hendak dibentuk tetap merupakan komponen yang sangat penting. Tanpa itu, mustahil sebuah pengadilan hibrida dapat terwujud.

\section{DAFTAR BACAAN}

\section{Buku}

Cryer, Robert, et.al., An Introduction to International Criminal Law and Procedure (Cambridge University Press 2010).

Ivaniševiæ, Bogdan, 'The War Crimes Chamber in Bosnia and Herzegovina: From Hybrid to Domestic Court' (International Center for Transitional Justice 2008).

\section{Jurnal dan Kertas Kerja}

American Society of International Law ASIL, 'Genocide and War Crimes in National Courts: the Conviction of Rios Montt in Guatemala and its Aftermath' (2013) 17 Insight.

Doyle, Kate, 'Justice in Guatemala' (2012) 45 NACLA Report on the Americas 37.

Öberg, Marko Divac, 'The absorption of grave breaches into war crimes law' (2009) 91 International Review of the Red Cross 163.

Martin-Ortega, Olga, dan Johanna Herman, 'Hybrid Tribunals \& the Rule of Law: Notes from Bosnia \&
Herzegovina \& Cambodia' (2010) 7 JAD-PbP Working Paper Series 6.

Möller, Christina, 'Gerhard Werle: Völkerstrafrecht (International Criminal Law): Book Review,' (2004) 5 German Law Journal 425.

Rikhof, Joseph, 'Fewer Places to Hide? The Impact of Domestic War Crimes Prosecutions on International Impunity' unpublished paper, ttp., tth.

\section{Seminar}

Skinnider, Eileen, 'Experiences and Lessons from "Hybrid" Tribunals: Sierra Leone, East Timor and Cambodia' (Symposium on the International Criminal Court, Beijing, Pebruari 2007). 